\title{
FAZER ETNOGEOGRAFIA NA CIDADE: AS PRÁTICAS ESPACIAIS DAS REDES E MICROCULTURAS JUVENIS DA PERIFERIA EM TORNO DA FESTA DO FLUXO
}

\author{
Élvis Christian Madureira Ramos \\ Professor e pesquisador pela Universidade Federal de Mato Grosso do Sul \\ UFMS/CPAN \\ elvis.ramos@ufms.br
}

\begin{abstract}
RESUMO
A festa do fluxo permite, com base na etnogeografia, revelar a força aglomerativa e autônoma da explosão de agenciamentos juvenis nas periferias urbanas. Saindo de bairros periféricos, estes jovens elaboram capital espacial para transpor as escalas na cidade e estabelecer circuitos e territorialidades. Ao mesmo tempo, criam dissidências sociais, territoriais e estéticas na cidade. Trata-se de uma festa juvenil inserida em um circuito de lazer paralelo, com suas formas próprias de sociabilidade, consumo e visibilidade social.
\end{abstract}

Palavras-chave: Etnogeografia. Práticas espaciais juvenis. Periferia urbana. Escalas geográficas. Capital espacial.

\section{DOING ETHNOGEOGRAPHY IN THE CITY: SPATIAL PRACTICES OF OUTSKIRTS' YOUTH MICROCULTURES AND NETWORKS IN FLOW PARTIES}

\begin{abstract}
Flow parties, based on ethnogeography, reveal the agglomerative and autonomous force of the explosion of youth arrangements in urban outskirts. Leaving neighborhoods on the outskirts of the city, these youngsters elaborate space capital to transpose the scales in the city and establish circuits and territorialities. At the same time, they create social, territorial, and aesthetic dissent in the city. It is a youth party inserted in a parallel leisure circuit, with its own forms of sociability, consumption, and social visibility.
\end{abstract}

Keywords: Ethnogeography. Youth spatial practices. Urban outskirts. Geographic scales. Space capital.

\section{INTRODUÇÃO}

Em geral, a festa do fluxo ${ }^{1}$ escapa da regulação do poder público, implica um espírito festivo anárquico, libertino e pulsante no espaço - algo que destoa e muito das festas organizadas e oficiais da cidade. É uma instância de diversão para os jovens que praticam o lazer noturno mais agitado e descontraído, ao mesmo tempo possibilita que se distanciem do efeito panóptico e de controle dos pais e autoridades a que estão submetidos no dia a dia.

Num sentido mais estrito, a festa do fluxo é uma prática social e espacial de caráter fortemente juvenil que emerge das periferias populares urbanas. Está presente não apenas nas grandes metrópoles, como São Paulo e Rio de Janeiro, mas também em algumas cidades não metropolitanas. Além disso, é uma festa ao mesmo tempo dissimilante e divergente, ou seja, na festa são produzidas formas de visibilidade social por parte dos praticantes ao mesmo tempo que estabelecem uma divergência estética e social na cidade.

Outro aspecto dessa festa juvenil está em integrar várias redes e microculturas urbanas, porém, mais que delimitar pequenos grupos juvenis em torno de suas práticas, esse trabalho inclui as relações desses grupos entre si e com aspectos identitários e de estilo cultural presente na festa.

Para enfrentar os desafios quanto o entendimento de uma festa que reúne diversas práticas juvenis e que se constitui de uma heterogeneidade de microculturas urbanas, este trabalho se apoiou na

${ }^{1}$ As palavras em itálico indicam conceitos êmicos ou nativos, oriundos dos próprios praticantes.

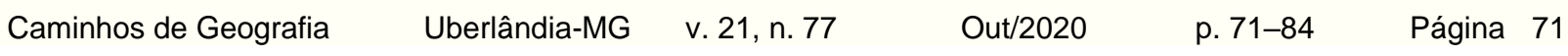


descrição etnogeográfica, cujo foco está na compreensão qualitativa das espacialidades produzidas pelos agentes sociais no âmbito de suas práticas e enredamentos.

Com efeito, a descrição etnogeográfica na cidade, se insere como uma descrição problematizadora, não somente incorpora as territorialidades e identitarismos das redes juvenis, como parte de outras indagações, como, por exemplo: Como estas práticas são criadas pelos praticantes dentro dos seus contextos sociais e espaciais ? Estas práticas também não seriam formas dinâmicas e vivas de produção do espaço urbano? Afinal, não estariam também construindo espacialidades numa dimensão mais autônoma? Até onde pode-se ainda pensar em grupos e microculturas isolados no espaço urbano, ignorando suas conexões socioculturais em diferentes escalas? E, se há fragmentação urbana, então como os grupos e redes sociais encontram formas de integração e conseguem partilhar isso numa cidade cada vez mais cindida socioeconomicamente?

Trabalhos pioneiros como de Magnani $(2002,2005)$ já destacavam a diversidade de circuitos juvenis na metrópole e a heterogeneidade de estilos, reforçando a ideia de que apesar de um espaço fragmentado, os jovens produziam no âmbito da diversão vários sentidos de espacialidades e coesão na cidade. A partir dessa via, propusemos aqui avançar na compreensão de como os jovens criam seus recursos e como especificamente os jovens das periferias enfrentam as barreiras espaciais e sociais, tendo em foco a festa do fluxo.

Em realidade, essa abordagem focada na produção espacial dos agentes sociais atenta para uma compreensão mais aberta à diversidade de práticas sociais e espaciais na cidade, que muitas vezes são encobertas nas narrativas mais amplas. Nesse sentido, este trabalho se junta com outros trabalhos que vêm surgindo nas pesquisas geográficas - sobre gêneros, grupos etários, culturas urbanas entre outros segmentos sociais -, que buscam destacar que a cidade vive uma explosão de diversidade sociocultural.

Esta dinâmica de pluralidade produz diversas formas de espacialidade e revela uma cidade muito mais complexa, labiríntica (HIERNAUX, 2006) e indefinida que aquela que estamos acostumados a reproduzir nos discursos mais unidirecionais. Isso também significa que a descrição etnogeográfica tem que ir além da visão dos agentes, como sujeitos passionais e fixos nos espaços. É preciso revelar a natureza da luta no espaço e pelo espaço, as conflitualidades ou dissidências no espaço urbano.

Para os segmentos sociais e microculturas marginalizados ou estigmatizados o espaço não está dado. O espaço é parte de uma geometria de poder (MASSEY, 2004; 2008;2017) em que tais segmentos precisam reunir capital espacial e outros capitais, como econômico e social, para conseguir visibilidade e o direito de ser na cidade (RAMOS, 2018). É lidando com as barreiras materiais e simbólicas e tentando superá-las que os agentes criam inovadoras formas de espacialidades, que fazem parte da "invenção do cotidiano" (CERTEAU, 1994).

$\mathrm{Na}$ verdade, o que se busca com um olhar geográfico mais atento aos praticantes da cidade, é o de dar voz e corpo à vida urbana e abrir fissuras nas perspectivas solidificadas sobre a cidade. Apesar dos avanços nos estudos sobre as reestrurações urbanas e na cidade, ainda se dá pouca atenção ao fato de que as mudanças nas formas e estruturas urbanas ocorrem por meio da renovação da vida social no próprio espaço, por isso, se faz necessário superar uma ideia um tanto contumaz que é pensar nas pesquisas sobre microterritorialidades como um tipo de estudo socioespacial isolado em si mesmo.

Para desenvolver a descrição e compreensão da festa do fluxo, este trabalho se constitui da seguinte estrutura: se inicia detalhando o que fundamenta a etnogeografia para o propósito deste pesquisa; em seguida destaca a inserção da periferia urbana nas conexões simbólicas e identitárias, explica como se formam as redes juvenis da periferia relacionadas à festa do fluxo, descreve as microterritorialidades e escalas que a festa produz na cidade e, por fim, discute os aspectos do consumo e as formas de dissimilação social que dela resultam.

Ao longo do texto, os conceitos articuladores da pesquisa, tais como, capital espacial, escalas e microterritorialidade são desenvolvidos junto com os contextos das descrições. O que visa dar fluidez ao texto e ao mesmo tempo, que surgem junto das práticas espaciais que os correspondem ou que os tensionam. Aliás, esse aspecto merece alguma consideração, pois os praticantes, na escala do cotidiano, às vezes revelam desde práticas novas até variações do que em teoria já está estabelecido como um conceito geográfico, por isso, nessa pesquisa, os conceitos êmicos, que originam-se das 
sociabilidades das redes juvenis e que dão nome para algumas de suas práticas espaciais, não se restringem a uma questão semântica, também podem indicar formas originais de produzir espacialidades na cidade.

\section{O FAZER ETNOGEOGRÁFICO EM TORNO DA FESTA JUVENIL DO FLUXO}

A etnogeografia desenvolvida neste trabalho se apoia nas observações e descrições das práticas sociais e espaciais de agentes sociais, busca não dissociar essas práticas daquilo que os próprios agentes entendem por meio de suas categorias nativas ou êmicas.

Ao mesmo tempo, é necessário entender como os agentes produzem suas diversas formas de espacialidades e sociabilidades, como determinam suas redes sociais, como estabelecem suas conexões culturais internas e externas e, dessas interações, o que eles selecionam e ressignificam que constituirão o universo de seus elementos diacríticos e de suas performances. Para tanto, levouse em conta o contexto socioespacial urbano, como a própria periferia urbana e a condição de classe. Não obstante, a compreensão dessas práticas espaciais e sociais juvenis também se desdobram na dimensão política (relações de poder, contestações, divergências), da ética (costumes, condutas e normas), da estética (sensações, percepções e gostos).

Deve-se destacar que em substituição a "grupos sociais", utilizamos o conceito de "redes sociais e/ou redes juvenis". No âmbito da análise das práticas juvenis observa-se que seus enturmamentos não estão fixos num único elemento identitário, suas interações se dão numa esfera social mais flexível em termos de vínculos pessoais e afetivos. Em grande parte dos casos, seus enturmamentos manifestam-se como "redes territoriais" (RAFFESTIN, 1993, p.204) que se espalham e se articulam pelo espaço, de modo flexível, moldando-se sob várias condições e possibilidades. Aspecto esse que o trabalho com culturas juvenis realizado por Turra Neto (2012) já compreendia quanto a formação de redes de sociabilidade e territorialidades dessas culturas na cidade.

Em termos de recorte geográfico, a descrição da festa do fluxo neste trabalho ocorreu na cidade de Bauru (SP), cidade com aproximadamente 340 mil habitantes (figura 1):

Figura 1 - Bauru (SP): Localizações flutuantes das festas do fluxo na periferia da cidade.

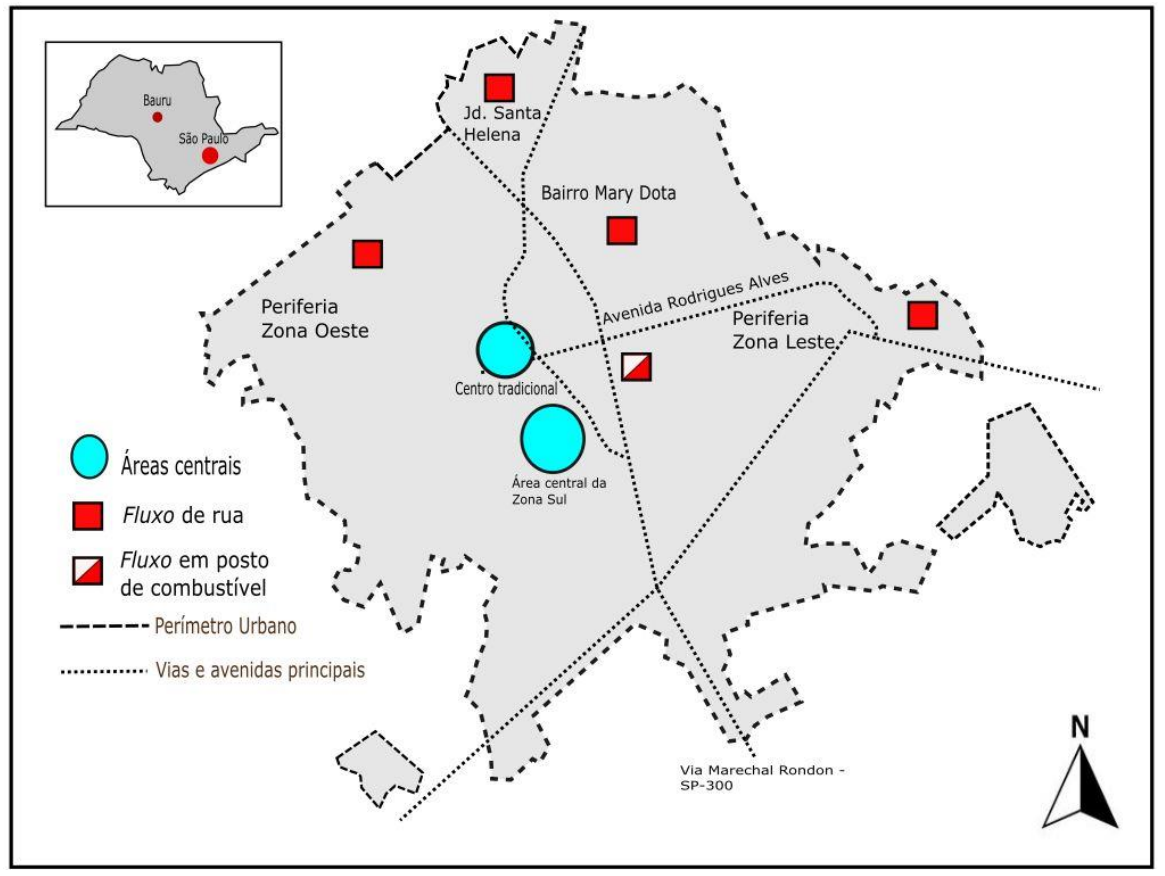

Fonte - Autor (2018) 
A entrada na periferia e redes sociais envolvidas com a festa se deu sob diversas instâncias observacionais e interativas. De início, ocorreu com a construção de aproximações e contatos interpessoais face a face e com observações in situ, ambas muito facilitadas pelas experiências anteriores deste observador no papel de professor da rede pública em bairros da periferia de Bauru. Esta longa experiência profissional permitiu construir uma ampla rede de colaboradores pertencentes a várias microculturas juvenis.

Contudo, a festa do fluxo costuma se desenvolver numa zona de penumbra social e marginalidade; por isso, a maior proximidade para estabelecer contatos e interlocutores não significa que as observações ocorreram sem dificuldades, inclusive porque estar com eles não significa ser um deles. Vieses e filtros entre as partes surgem em qualquer pesquisa qualitativa e de contato interpessoal; além disso, algumas práticas são ocultadas, já que muitos arranjos entre os jovens ocorrem de modo fechado e nas zonas mais internas de suas redes sociais.

Em face disso, o trabalho com jovens e adolescentes em relação às entrevistas e conversas costuma transcorrer com lacunas, entrelinhas e reticências. Deve-se também salientar um ponto sempre presente neste tipo de pesquisa, que é o fato desses jovens saberem descrever suas práticas de modo factual, mas, por não estarem acostumados com este tipo de questionamento, têm dificuldade para externalizar aos outros que estão fora de suas redes, os detalhes sobre suas sensações e o que as práticas que realizam significam para eles em termos de visibilidade e fruição.

Um jovem, por exemplo, diz na entrevista que a prática do "rolê é legal", mas o que é esse "legal"? O que é sair para dar rolê? Em geral, os rolês são práticas espaciais que formam circuitos de diversão. No caso dos jovens das periferias, somam-se as transposições de escala para poderem de fato fazer seus circuitos na cidade. Contudo, qual é o sentido de fazer um rolê enquanto prática espacial enturmada com outros? São questões como essas, que impõe um outro desafio: o observador precisa entrar no "jogo de linguagem" presente nas suas redes sociais.

Em outras palavras, sem entender as regras e o contexto em que os praticantes usam seus termos, não é possível fazer qualquer correspondência ou interpretação que se aproxime da essência de suas práticas e intencionalidades ou dos conceitos geográficos. Sobre isso, é importante que se destaque devidamente a distinção entre perspectiva ética e êmica sobre as práticas dos agentes. Foi - linguista Kenneth Pike que a introduziu, chamando de abordagem ética os comportamentos linguísticos dos praticantes vistos de fora, isto é, sob análises e julgamentos externos e, de abordagem êmica o significado desses comportamentos no entendimento dos próprios agentes (OLIVE, 2014).

Com efeito, tal distinção se demonstrou profícua nos estudos sociais e culturais. Como destacou Barth (2000), ela possibilitou reinterpretar a ordem epistêmica de observação e compreensão sobre os praticantes, pois não só realçou a importância das categorias nativas, como também possibilitou confrontá-las com as categorias daqueles que os observam. Entende-se, com isso, que as práticas espaciais têm não somente um modo de ser construídas por seus praticantes como também um sentido interno derivado de suas redes de sociabilidades. Assim, o universo êmico impõe ao pesquisador maior atenção aos contextos e ao significado das práticas para aqueles que as fazem.

$\mathrm{Na}$ observação in situ, as festas foram acompanhadas do seu início ao ponto alto. A vantagem de assistir ao começo da festa foi o de identificar e entender a formação dos agrupamentos das redes e microculturas no espaço da rua, ou seja, suas microterritorialidades. A observação em trânsito também foi crucial, pois é acompanhando os jovens na ida para a festa e no retorno dela, ou nos momentos em que a festa muda de lugar, que se pode constatar o poder de suas redes em criar a aglomeração festiva do fluxo. Neste caso, estar circulando de motocicleta pelas ruas e festas facilitou muito, pois permitiu atingir vários pontos do espaço urbano com rapidez e observar e interagir de forma muito mais ampla.

Não obstante, é necessário buscar outras fontes também válidas de informação, a fim de preencher as lacunas derivadas das observações diretas e entrevistas, o que implica variadas estratégias de acesso à informação. Esses outros recursos se compuseram com base na netnografia (KOZINETS, 2014), que é a observação e o contato por meio das interfaces sociodigitais, que facilitaram o acesso às informações sobre como os jovens do fluxo organizam suas festas. Uma estratégia central foi ser aceito em dois grupos fechados do Facebook. Com essa plataforma, foi possível registrar 
depoimentos, relatos e fotos que permitiram completar muitas lacunas, sobretudo em torno das estratégias relacionadas à realização da festa.

Com base no estudo dos primeiros registros e das hipóteses deles decorrentes, foram formulados cinco núcleos de observação e análise: 1) como os jovens em suas redes se articulam para a festa do fluxo; 2) como conseguem encontrar meios para transpor as escalas na cidade; 3) como exercem suas formas de apropriação material e simbólica dos espaços; 4) como as redes e microculturas juvenis presentes na festa exercem suas performances e interação com os outros e 5) como desenvolvem e expressam suas práticas de consumo e visibilidade social. Esses núcleos de descrição e análise são formulados na sequência desse trabalho.

É preciso destacar que todos os núcleos de observação e análise tinham como premissa central que a festa do fluxo era constituída do enredamento de diversas redes juvenis para formar uma aglomeração espacial festiva, mas que, de forma subjacente e prévia, requeria a construção de capital espacial (RAMOS, 2017, 2018), isto é, recursos e habilidades primárias que de fato possibilitam o movimento e a coordenação no espaço, sem esse capital, não há como desenvolver outras formas de espacialidades para seus encontros.

Também é oportuno destacar que as práticas espaciais encontradas entre os agentes sociais não só reforçam a variedade das espacialidades existentes entre as culturas e redes sociais como também encontram fundamentos explicativos em conceitos geográficos importantes de outras pesquisas. É o caso, neste trabalho, da concepção de transposições de escalas (SMITH, 2000), da ideia da construção das escalas construídas socialmente (MARSTON, 2000), da importância da busca da visibilidade social no espaço (RAMOS, 2018) e dos aspectos simbólicos e classificatórios que atuam na diferenciação das classes e também dos espaços sociais (BOURDIEU, 2007). Justamente este diálogo e tensão entre prática e teoria que permite avançar na compreensão científica também dos fenômenos sociais e espaciais de forma dinâmica e renovada.

\section{O CONTEXTO DAS RELAÇÕES TRANSTERRITORIAIS NAS PERIFERIAS URBANAS}

A festa do fluxo pode ser encarada como uma parte da "cultura da periferia" (NASCIMENTO, 2010), pois além de se externalizar culturalmente saindo dos bairros populares periféricos, também estabelece um circuito de lazer paralelo ao circuito formal e mercadológico da cidade. As diversas fontes orais e informações jornalísticas parecem sugerir que o fluxo derivou dos bailes funk na cidade do Rio de Janeiro nos anos 1990. Esses bailes se transformaram numa "cultura viajante" (CLIFFORD, 2000), migrando para diversas favelas, bairros e cidades, ainda que sob estigmatização e marginalidade cultural (GUIMARÃES, 1997).

De qualquer forma, há certo consenso sobre que, dos bailes nos morros ou nas favelas, os jovens desceram para as ruas devido ao baixo custo da diversão e pelo engajamento livre de restrições territorialistas. Num movimento transterritorial, essa cultura juvenil popular alcançou outras regiões e cidades, como a Baixada Santista e a cidade de São Paulo. Somente na cidade de São Paulo existem atualmente mais de uma centena de fluxos ${ }^{2}$ em ruas das periferias.

O fluxo chegou a Bauru e provavelmente para outras cidades não metropolitanas à medida que aumentou o grau de conectividade e o aumentou o trânsito de conteúdo cultural entre as periferias. Isso se deu, sobretudo, em função dos sistemas e plataformas digitais que massificaram o compartilhamento de conteúdos simbólicos e culturais. Seus pontos de acesso se ampliaram na periferia, como as lan houses, que foram de vital importância para essa conectividade entre lugares (RAMOS, 2017). Contudo, isso não explica totalmente por que a festa se espalhou além dos centros metropolitanos.

Uma hipótese é a conexão identitária e êmica preexistente nas periferias populares desde os anos de 1990. Ela se deu com a emergência de algumas culturas urbanas da periferia, como hip hop, que nesse período foram pioneiras em abrir circuitos de festas e encontros não somente em escala intraurbana como também interurbana, favorecendo a incorporação de culturas urbanas metropolitanas em cidades do interior (TURRA NETO, 2012; RAMOS, 2017).

2 Fonte: Informativo Ponte, canal de comunicação de segurança pública e direitos humanos e dados da Polícia Militar de São Paulo, por meio de mapeamento destes encontros na cidade. Disponível em: http://ponte.org/em7-meses-6-funkeiros-sao-assassinados-em-bailes-de-sp/. Acesso em 23/4/2014.

\begin{tabular}{|c|c|}
\hline Caminhos de Geografia & Uberlândia-MG \\
\hline
\end{tabular}


Com a disponibilidade de novos meios informacionais e das redes sociodigitais, o nível de compartilhamento foi multiplicado entre os jovens desses bairros. Com postagens na internet, a própria produção cultural da periferia passou a se projetar mais amplamente, o que estabeleceu uma cultura transterritorial da periferia, isto é, não mais circunscrita e isolada nos bairros dos grandes centros, mas que se espalhou e se identificou entre as várias periferias urbanas. Assim, a periferia também se tornou um lugar de centralidade cultural e de ligação entre lugares, e a festa do fluxo é mais uma cultura urbana a carregar uma parte do ethos dessa periferia popular transterritorial. Por exemplo, muitas das músicas de funk originadas nas metrópoles faziam alusão ao fluxo, as letras contavam sobre os circuitos de jovens por essas festas, como um lugar de encontro das favelas e bairros pobres. A abertura e receptividade dessas músicas nos bairros pobres de cidades não metropolitanas permitiu assimilar entre outras tendências, o fluxo como uma festa autêntica da periferia.

De modo estrito, essa cultura juvenil chega e se fixa em Bauru nos anos de 2010, de início ela é confundida com os bailes funk, que ocorrem em alguns bairros da periferia da cidade. Os primeiros fluxos que ocorrem são nos pátios de postos de combustíveis, que como veremos a frente é uma de suas formas territoriais. Outro elemento determinante foi a oferta de bebidas alcoólicas e refrigerantes nesses postos que favoreceram a concentração de jovens nestes locais, e porque também não cobravam para usufruir dos seus pátios. Algumas redes sociais juvenis, como os jovens do som automotivo foram algumas das redes juvenis e microculturas que mais impulsionaram o fluxo na cidade.

A festa do fluxo acaba sendo na realidade parte da produção social da periferia popular e que se tornou mais diversificada e interconectada. Mesmo os estudos de geografia urbana voltados à estrutura urbana ignoravam que esses vastos e populosos espaços urbanos também desenvolviam seus próprios sentidos culturais, estéticos e simbólicos em relação à cultura hegemônica e massificada (NASCIMENTO, 2010).

\section{OS ENREDAMENTOS JUVENIS EM TORNO DA FESTA DO FLUXO}

A festa do fluxo tem em sua verve festiva aquela "pulsão do estar juntos" (MAFFESOLI, 1998), que, para os jovens, é o sentimento de prazer em viver uma experiência com os seus, com aqueles que se reconhecem como parte de certo tribalismo, aqueles que partilham gostos e interesses. Mas, afinal, como essas redes se formam na periferia e como isso resulta na festa do fluxo?

Apesar de a festa resultar da articulação de redes juvenis espalhadas em diferentes bairros periféricos, tudo começa primariamente com aquilo que Maffesoli (1998, p. 35) chama de "encadeamento proxêmico", isto é, laços construídos no dia a dia, na proximidade física, na convivência nos mesmos espaços sociais. É nas relações miúdas que vão se aproximando e partilhando gostos e novidades. Nesses encadeamentos de jovens, os espaços da escola, da rua e da quadra no bairro se tornam essenciais para estimular um sentimento gregário em torno de interesses em comum.

A festa do fluxo é mais um espaço onde partilham essa força gregária e podem vivenciar uma diversão entre os seus. A diferença é que a festa do fluxo é em si um enturmamento que abrange uma significativa pluralidade de redes e microculturas da periferia, uma interação massiva e heterogênea que costuma ser conhecida entre os jovens como tudo junto e misturado. Outro aspecto específico da festa é que, enquanto nos chamados rolezinhos para os shopping centers a esmagadora maioria é de jovens adolescentes, os jovens que participam do fluxo são de diversas faixas etárias, mas a maioria tem mais de 18 anos. Em geral são jovens que têm mais autonomia e liberdade para atravessar as madrugadas na cidade.

Muito frequentemente a festa não costuma ter uma liderança ou uma alguma forma de organização que a presida; porém, isso não significa que não haja uma ou mais iniciativas que a deflagram. Isso significa que as mensagens, sobretudo por meio das plataformas sociodigitais, serão multiplicadas e compartilhadas entre os jovens e suas redes de amizades, gerando uma onda de interesse que se consolida e que pode resultar na realização da festa em algum lugar da cidade.

As páginas de grupos fechados no Facebook, por exemplo, exercem um papel importante. Por meio dessa interface, os jovens também combinam a localização ou mudança da festa. Discutem o que 
devem levar ou convidam outras redes e microculturas para formarem o tudo junto e misturado. Nessas páginas também há 0 aviso quantitativo daqueles que têm interesse e daqueles que confirmam o comparecimento. Todos esses aspectos proporcionam as condições para a festa acontecer. Uma postagem numa plataforma sociodigital a seguir informa, com todas as nuances da linguagem dos jovens, um pouco sobre o que se espera em termos de diversão na festa:

\#xaaama geral pro fluxo da zona norte vem pro baile de favela que vai ta gostosin encosta cas motoca e \#xaaama no graau e os carro e o fluxo comendo solto soom liberado traz os **** \#os \#goro vamo para o gaspa geral de todas quebrada convidado vamo curti na disciplina sem pereco sem tumultoo \#chamaa as novinha $e$ parceiro e encosta na ultima \#rua do jardim helena \#geraal \#encostaaa não tem hora pra acaba vamo faze verdadeiro fluxo de rua ${ }^{3}$.

Uma festa de todos para a qual cada um traz o que pode, e juntos se aglomeram para curtir a diversão sem hora para acabar e outros constrangimentos. A festa é também um momento de trégua, onde se busca deixar as diferenças pessoais e territoriais de lado.

Por isso, para que a festa de fato dê certo, ela precisa criar esse enturmamento de várias retículas juvenis espalhadas nos mais diversos pontos da periferia. Não é uma confluência que segue regras e hierarquias programadas, mas ocorre de forma rizomática, ou seja, brotando e se ramificando pelos bairros e encontrando um fluxo, uma direção, uma aglomeração. E são essas características que definem o fluxo como uma prática social e espacial. É com essa multidão reunida que novidades aparecem, como batidas musicais, jovens empinando motos, bebidas, brincadeiras etc. Uma territorialidade festiva e fluida que constitui um nó de diversas redes e microculturas juvenis.

Entre as muitas redes e microculturas que participam do fluxo, costumam aparecer os jovens do low (que curtem carros com suspensões rebaixadas), jovens do wheeling (que realizam acrobacias com as motos empinadas) e jovens das batidas (que investem em aparelhagem de som automotivo e rachas de som). Há também a presença dos bondes, ou turmas de amigos que se formam no bairro ou que se entrincheiram nele, jovens unidos para viver juntos as diversões, defender-se dos inimigos, unir-se em brigas e bebedeiras - sempre juntos e irmanados nos rolês.

Um atrativo crucial para todos estes jovens é o fato de que o custo para se divertir no fluxo é muito baixo ou quase nenhum. Além disso, é apenas ir e se divertir: não há exigência de pagamento de entrada ou algum limite de idade. Não são obrigados a consumir na festa, mas, se quiserem e não tiverem dinheiro, podem contar com a rede de amigos para partilhar um lanche ou a bebida, como destacou um jovem que entrevistei4: "Se você chega sem grana, sempre tem um amigo que salva". Enfim, é uma opção barata de lazer. Pablo, um estudante universitário de 19 anos um interlocutor e que costumava ir ao fluxo, foi enfático ao afirmar que os amigos "escolhiam ir para a festa porque ninguém tinha nada para fazer, não tinham lugar para ir", porque as baladas são caras em sua maioria. Nesse sentido, o fluxo acaba sendo uma alternativa de diversão ao alcance de qualquer um.

\section{AS ESPACIALIDADES PRODUZIDAS EM TORNO DO FLUXO}

O modo fluído e não hierárquico de se enredarem no espaço em torno do fluxo constitui em essência as microterritorialidades reticulares e rizomáticas dos jovens da periferia. Contudo, é preciso descobrir como essas microterritorialidades são construídas e seus desdobramentos, ou seja, como produzem suas escalas de movimento transpondo os limites de seus bairros, criando circuitos de diversão na cidade nas suas aglomerações espaciais, rasurando espaços públicos e privados e coordenando a realização da festa com suas quebradas ou pedaços.

De início todas as redes juvenis e microculturas da periferia dependem, para suas práticas, de certo tipo de capital espacial que mobilizam numa esfera individual, familiar ou coletiva e que primariamente é a fonte de suas iniciativas sociais e territoriais no campo da diversão (RAMOS, 2018).

${ }^{3}$ Festa do fluxo que ocorreu no Jardim Helena, em Bauru, na Zona Norte da cidade no ano de 2016 (figura 1).

4 R.M.F é um jovem de 17 anos, estudante do Ensino Médio, morador do bairro Octávio Rasi. Ele e outros amigos juntos formam um pedaço, um território onde se reúnem e fortalecem suas redes.

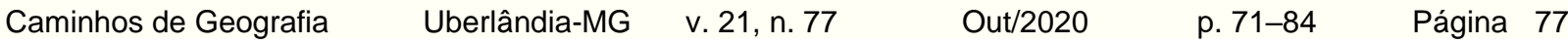


No âmbito individual, alguns jovens podem de início morar em lugares que mesmo na periferia estão em regiões acessíveis e bem servidas de transporte coletivo. Outros podem não ter essa vantagem locacional, mas podem ter alguma motorização (carros ou motos). Há também a possibilidade de conhecimento prévio do espaço, que é em si um capital espacial adquirido desde a adolescência, quando aprendem a circular na cidade e se familiarizam com os lugares a ponto de se sentirem seguros para se deslocar.

Esse capital espacial também se associa a outros capitais, como o capital social no nível de suas interações proxêmicas, ou seja, da ajuda mútua que emana de suas redes sociais. Com essas amizades e interações podem combinar lugares de encontro para se juntarem e, assim, se sentirem mais engajados para irem para a festa ou outros lugares. É em suas redes sociais que encontram caronas e cotizam dinheiro para poder usar serviços de transporte e se movimentar no espaço.

Nesse sentido, o capital espacial não está relacionado apenas a uma condição fixa e imóvel de se reunir condições locacionais vantajosas no espaço, mas também ao fato de os agentes sociais usarem de recursos e habilidades aprendidas para se movimentar e ter acessibilidade aos lugares.

Esse movimento é o que faz com que possam produzir escalas na cidade, transpor barreiras, isolamentos e fronteiras na cidade. Porém, é preciso esclarecer que a compreensão teórica e empírica do conceito de escala geográfica ou espacial vem se aprofundando nas últimas décadas. Mais que uma forma de raciocínio espacial, a escala passou a ter um sentido de construção social (MARSTON, 2000). Ela é construída na sua extensão pelo movimento dos agentes sociais. Desse modo, não é a escala que previamente determina a extensão do fenômeno, mas é a ação dos agentes que, neste caso, determinará as escalas pelas quais se materializa na cidade a amplitude de seus movimentos e territorialidades, assim como suas conexões com outros lugares (CASTRO, 2009). Por exemplo, circular na cidade, transpor barreiras e limites materiais e simbólicos é produzir escalas $(\mathrm{SMITH}, 2000)^{5}$

Os jovens da periferia, aliás, não diferentes de outras redes e segmentos que também produzem suas escalas, realizam seus movimentos, fluxos e transposições de limites e fronteiras na cidade. Um fator importante para o salto de escalas é o próprio capital espacial relacionado ao aumento da motorização (motos de baixas cilindradas e automóveis usados) entre as classes populares desde os anos 2000 (RAMOS, 2018).

Outro fator, no caso de Bauru, se deu com à oferta, ainda que precária, de transporte urbano com ligações interbairros e de passagens de integração entre linhas urbanas, o que favoreceu a acessibilidade a vários pontos do espaço urbano além daqueles que se situam no sentido centro e bairro.

Esses aspectos e mais a capacidade de se comunicarem em tempo real por meio de diversas plataformas sociodigitais abriram para estes jovens um campo de possibilidades para circular e romper barreiras espaciais e se projetarem além de seus bairros. A motorização em massa e a logística mais ampla de transporte urbano se tornaram, assim, um capital espacial para essas redes juvenis periféricas construírem suas escalas e uma "multiterritorialidade" (HAESBAERT, 2012) na escala intraurbana. Portanto, além de as retículas juvenis criarem o enturmamento para a festa, também é necessário que articulem diversos recursos e competências para se mover no espaço.

A festa pode, por exemplo, ser realizada no trânsito das retículas juvenis na cidade. Um fato interessante ocorreu numa das observações que realizava em torno do rolezinho, ${ }^{6}$ que foi desbaratado pela intervenção policial. Naquele mesmo momento, alguns jovens que me acompanhavam nas observações estavam sendo avisados nos seus grupos de WhatsApp que um

\footnotetext{
${ }^{5}$ Um estudo conhecido de Neil Smith (2000) a este respeito trata da transposição de escala por agentes sociais na cidade, em como ampliam seus espaços de relações e adquirem visibilidade social.

${ }^{6}$ Rolezinhos é outro tipo de prática espacial juvenil que se relaciona com os circuitos dos jovens da periferia que buscam visibilidade social e encontros em shopping centers e/ou outros espaços de consumo (Ver RAMOS, 2015). 
fluxo estava sendo organizado num ponto da cidade e para onde muitos estavam indo. Esse poder de se articularem em tempo real e o efeito multiplicador das suas mensagens é justamente o que permite o poder aglomerativo da festa.

Não obstante, é preciso reforçar o que é esse poder espacial aglomerativo dos jovens da periferia e que se materializa com a festa do fluxo. Inicialmente, a aglomeração ou formação de multidões é um fenômeno relacionado à cultura de massa desde o século XX e que se enraizou nas culturas juvenis, como nos shows de rock. Alguns sociólogos, como Pallarés e Feixa (2000), destacam que os jovens passaram a buscar as multidões como lugares de vida social mais intensa. Para Maffesoli (1998), isso indicaria ainda a força da vida gregária sobre o individualismo. Apesar de tal constatação ser um fato social e espacial, deixa-se de fora a própria explicação do processo, que pode variar entre segmentos sociais e microculturas.

Os jovens da periferia, como já anteriormente salientado, tecem suas relações proxêmicas em espaços comuns, como na rua, nos campinhos de futebol e na escola. Desenvolvem habilidades sociais e espaciais num ambiente de escassez de recursos e oportunidades. Acostumam-se com o gregarismo e as multidões, pois qualquer atividade é uma forma de sair da mesmice do bairro e da falta de lazer.

Outro sentido da aglomeração está na capacidade de multiplicar as sensações e prazeres em meio a gente conhecida ou que partilham os mesmos interesses. E a festa do fluxo é uma dessas oportunidades, já que permite a esses jovens viver, num espaço concentrado, uma mistura de sons, cheiros, cores e pessoas. Também estabelece uma forma de conexão geracional e cultural em que o espaço é a condição, o meio e o produto das práticas festivas.

É também onde descobrem o poder espacial da aglomeração. E, no caso do fluxo, isso é uma condição básica para manterem a festa. É do poder de se aglomerarem que deriva a força para se apropriarem do espaço por mais tempo e até mesmo frustrar as investidas das autoridades e da polícia, que costumam impedir ou desfazer a festa.

Em relação à territorialidade da festa, pode-se distinguir na cidade os fluxos de rua; os fluxos praticados em pátios de postos de combustíveis e os fluxos que podem ser chamados de fluxos das quebradas.

O fluxo de rua é o mais popular e ao mesmo tempo o mais inclusivo e aberto. Alguns são localizados em ruas ou praças conhecidas de alguns bairros da cidade. Costuma se dar de forma pacífica; contudo, a aglomeração de um fluxo de rua pode praticamente fechar o tráfego de carros e pedestres. Além disso, as altas batidas sonoras podem também perturbar a tranquilidade da vizinhança, sem contar a sujeira que resta no final da festa, o que não contribui para sua aceitação em alguns bairros.

O fluxo nos postos de combustíveis pode ocorrer por meio de uma microcultura que já faz do local um pedaço ${ }^{7}$, ou seja, um ponto de referência espacial e de encontro de uma rede juvenil. Contudo, à medida que se torna um local conhecido, outras redes e microculturas são atraídas para o lugar. Os fluxos em postos de combustíveis constituem um tipo de simbiose, pois há ganho para ambas as partes, ao menos temporariamente. Como será visto, às vezes o próprio posto pode ganhar má fama em razão da festa. De qualquer jeito, os postos oferecem uma dupla vantagem: espaço físico e condições de consumo, sobretudo de bebidas alcoólicas. Um jovem participante desse tipo de fluxo destaca que é uma diversão "barata, porque na casa noturna tem que gastar muito, mas no fluxo não gasta tanto".

Já os fluxos das quebradas costumam buscar outro tipo de local e construir outro tipo de territorialidade. Quando os jovens falam de fluxo da quebrada (e às vezes baile na quebrada), há uma plurissignificação êmica. Primeiro, é um lugar com forte apelo territorialista, dominado pelos manos ou redes juvenis fortemente irmanadas nos seus códigos. Em termos de estratégia espacial, esses fluxos

${ }^{7}$ Esse conceito nativo e as práticas que o corresponde foi também estudado por Magnani (2002; 2005).

$\begin{array}{llllll}\text { Caminhos de Geografia } & \text { Uberlândia-MG } & \text { v. 21, n. } 77 & \text { Out/2020 } & \text { p. 71-84 } & \text { Página } 79\end{array}$


visam estar longe do olhar da polícia. Segundo, é lugar de encontro dos amigos e daqueles que sabem curtir e consumir sem receio de constrangimentos e olhares de fora. Esse tipo de fluxo às vezes não tem um lugar fixo ou periodicidade definida. Na verdade, tem um perfil mais itinerante e transitório no espaço urbano.

É preciso destacar que os fluxos nos postos de combustível e/ou de rua podem adquirir má reputação, apesar dos esforços de alguns jovens ou redes para tentar assegurar uma festa pacífica. Alguns destes postos podem atrair redes juvenis que têm práticas de risco, como os rachadores, que buscam, pela automobilização, intensificar suas sensações de euforia com as corridas de carros ou motos em vias públicas (JEOLÁS, 2015). Além disso, jovens embriagados podem atirar garrafas e latas em ruas adjacentes ou, ainda, se inserir na festa por redes sociais relacionadas à venda de entorpecentes, o que gera a intervenção da polícia.

\section{AS MICROTERRITORIALIDADES NO INTERIOR DA FESTA}

Como vimos, as microterritorialidades das microculturas juvenis que fazem o fluxo se dão em função do poder em se constituir numa aglomeração espacial com finalidade festiva baseada num gregarismo heterogêneo de diferentes redes. Cada uma delas elabora, a partir de seu capital espacial, condições para criarem escalas e trânsito para as festas. A outra parte de suas microterritorialidades se dá propriamente fazendo a festa. Isso quer dizer que cada rede produz suas performances e visibilidade; cada uma demarca um uso do espaço da rua.

Esse é um ponto assaz pertinente. Em geral a territorialidade pode ser interpretada como um processo de apropriação material e simbólica que se faz pelos sujeitos, constituindo ou não uma relação de poder (HAESBAERT, 2012). A festa do fluxo se inscreve como uma forma de territorialidade na cidade; contudo, nela não se identifica força hierárquica e central. Ela se faz de forma rizomática, pois são redes que se articulam nas suas microterritorialidades sob diferentes capitais e escalas no contexto de seus cotidianos, sob miúdas relações com outras redes e que podem formar uma grande aglomeração espacial festiva.

Nesse sentido, a microterritorialidade não é determinada apenas pelo tamanho de uma rede social ou da apropriação de microespaços, também porque são retículas sociais que tecem suas interações sociais e espaciais entre brechas, aberturas e possibilidades que encontram entre as estruturas espaciais e que vão produzir suas próprias formas de uso do espaço.

$\mathrm{E}$, no caso da festa do fluxo, essas redes não se diluem numa massa identitária homogênea, mas preservam suas identificações e formas de visibilidade. São microterritorialidades que se veem projetadas na festa, ou seja, no fluxo serão encontradas diversas redes e microculturas, como os funkeiros, as meninas da balada, os jovens da ostentação, jovens do sertanejo etc.

Um olhar distanciado pode gerar a impressão de que todos constituem uma multidão quase homogênea, mas na realidade o fluxo acaba sendo uma instância para diferentes jogos de interação. Essas diferenças são observadas nas várias rodinhas de amigos que vão se formando e que demarcam, por sinais, códigos e regras, o modo como vão curtir a festa.

Em meio à festa, todos estão cientes de quem está próximo ou de quem chega. Gestos amigáveis são importantes para manter todos mais ou menos irmanados na festa. Sutis assentimentos com a cabeça e olhadelas de relance sem fixar diretamente os olhos são parte dos códigos de reciprocidade. São sinais de respeito que, embora o jovem ou a jovem não esteja na interação focada da rodinha, querem dizer algo como: "eu te percebo e não tenho nada contra você" - um tipo de sociabilidade muito próximo daquilo que Erving Goffman (2010) chamou de "desatenção civil", ou seja, um olhar fugaz para o outro e que logo se desvia para enunciar respeito e polidez.

Mas, apesar das atitudes de camaradagem e respeito mútuo, existe a necessidade de se preservar algum distanciamento físico. Cada rodinha de conversa, carro com som, uma mesa com amigos, constitui um tipo de microterritório. Contatos físicos como esbarrões ou chegar na festa e já ligar o som alto a ponto de se tornar competitivo com outro carro ao lado são algumas das atitudes que podem ser mal interpretadas. Por isso, chegar na humilde (sem muita ostentação) é uma forma de acordo para se preservar o clima de diversão. 
De qualquer forma é uma festa com muitas dissonâncias, pois são vários os estilos musicais e temas que estão no mesmo espaço. E a sonoridade múltipla e difusa é parte importante da construção desta ambiência juvenil e da "geração de sensações" (JEOLÁS, 2015). Além disso, as músicas funcionam como forma de coesão das microculturas, um "polo gregário" (PAIS, 2003), identificado por suas letras e expressões estéticas.

Alguns gêneros musicais que rolam no fluxo, como o funk, possibilitam criar performances dançantes, como o quadradinho de 8 ou o famoso passinho do romano. São coreografias que misturam diversos elementos estilísticos da dança e música: break, funk, pop e samba. Num dos fluxos observados, como o fluxo da leste, no bairro Mary Dota (figura 1), basta simplesmente a música liberar suas batidas que surgem alguns meninos ou meninas que podem protagonizar uma cena de dança. Esse espírito vibrante e anárquico do fluxo destoa muito das festas que se dão sob um único tema e controles mais centralizados.

Contudo, nos meios jornalísticos, nas páginas das plataformas sociodigitais e mesmo nas conversas do dia a dia, vigora o tom depreciativo e estigmatizante sobre as festas e encontros dos jovens das periferias, sejam elas as festas das galeras ${ }^{8}$, os bailes do funk, os encontros dos jovens do lowrider ou os shows de rap. E o fluxo não escapa dessa estigmatização.

$\mathrm{Na}$ verdade, é a festa juvenil que atualmente tem atraído maior reprovação, classificada em muitos meios sociais como a festa da favela num tom de menosprezo e aversão estética. Os julgamentos que se costumam atribuir ao fluxo vão de um antro de tráfico e gangues ao de um lugar de esbórnia e confusões. Por ser uma festa que reúne quem quiser ir, não há proibições ou controles que possam evitar os excessos na festa.

O problema desses julgamentos é que se tornam hegemônicos e de uma nota só, pois encobrem o fato de que grande parte das festas do fluxo ocorre sem confusão ou tumulto. Além disso, a maioria esmagadora de quem está na festa não quer confusões, quer apenas se divertir.

\section{CONSUMO E A MÚLTIPLA VISIBILIDADE SOCIAL NA FESTA DO FLUXO}

Em face dos estigmas que a festa carrega, o fluxo acaba sendo um território mais ou menos cinzento para os jovens em termos de visibilidade social pública. Diferentemente dos jovens dos rolezinhos, que gostam de postar suas performances nos espaços de consumo, como nos shopping centers, os jovens do fluxo em grande parte não gostam de dar ampla publicidade às suas práticas na festa. Contudo, a busca por diversão e liberdade não impede que realizem práticas de "dissimilação social" (BOURDIEU, 2007). Essas práticas, porém, se conformam àqueles que estão na festa, no espaço produzido social e simbolicamente.

Com efeito, além da fruição, dos sentidos torpedeados pelas batidas de som, os jovens que gravitam em torno dos carros, das rodinhas, das danças e coreografias também estão fazendo o jogo de aparências e projeções sociais construídas no tempo livre e numa escala microterritorial.

No trabalho de Diógenes (1998) sobre jovens da periferia, também se destaca que, nos momentos do baile e das festas, esses jovens querem registrar suas existências, buscam romper com certos limites de homogeneização. Pode-se dizer que o fluxo segue o mesmo princípio. Nesse aspecto, o espaço de diversão também é o de individualização, mas que só tem sentido entre os seus, no interior de suas redes sociais. São jovens que, na festa, fazem do corpo, do consumo e da ostentação de seus carros e motos meios de visibilidade social. O lucro desses esforços se dá na conquista de uma maior rede de amizades afluentes, reconhecimento, admiração, respeito e favorecimento com convites para festas e farras.

É preciso destacar que, nos moldes do pensamento bourdieuano, as dissimilações são práticas ajustadas a teoria dos campos, ou seja, se dá na disputa por trunfos, como poder, dinheiro ou outros recursos que ampliam as vantagens e posição social dos agentes num determinada topologia social (mapa das distancias sociais dos agentes).

${ }^{8}$ Destaca-se aqui o trabalho interessante de Guimarães (1997) sobre as práticas e estigmatização em torno dos jovens das galeras no Rio de Janeiro. 
Já a dissimilação social praticada pelos jovens da periferia é uma variação desse molde, pois de início não há um campo social instalado na festa do fluxo, ao menos não no sentido de forças em luta por lucros simbólicos e materiais ou, ainda, que almejam uma posição melhor na escala social ou domínio do campo social. A festa em si não é um campo de disputa de poder. A dissimilação atua junto das práticas de diversão; por isso, ainda que os jovens na festa do fluxo busquem construir suas visibilidades e obter certo reconhecimento entre os seus, não existe de modo superveniente a busca pelo poder e controle da festa.

Investem nas melhores roupas que conseguem adquirir, vão com seus carros e motos e se dispõem a consumir bens de consumo que thes agreguem mais notabilidade. A fruição da festa favorece a possibilidade de serem notados e de se destacarem, e isso significa ir além da invisibilidade que enfrentam no cotidiano e das formas de segregações que enfrentam. Na realidade, a festa do fluxo é um dos espaços que oferece condições para esses jovens se projetarem socialmente.

A grande maioria desses jovens mais envolvidos com práticas de ostentação não tem outras opções de lazer ou não curtem outros formatos de diversão. Acabam absorvendo das estruturas sociais e de suas experiências mais imediatas os modelos e valores da sociedade de consumo que os atingem. Muitos ignoram a mensagem do hip hop ou de outras identificações de ideário juvenil ditas mais contestatórias e políticas. Por isso, usam o espaço e a festa para afirmar e/ou conquistar mais prestígio e notabilidade por seus sinais diacríticos e de consumo.

Outro aspecto que chama atenção na festa é o alto consumo de álcool, o que mostra a forte penetração desse bem de consumo entre jovens da periferia. Na realidade, estes produtos estão em toda parte, em todos os bairros da periferia. Muito frequentemente os jovens têm amplo acesso à compra e consumo dessas bebidas, encontradas nos botecos, nas lojas de bebidas 24 horas, nos minimercados, nos postos de combustíveis. Na festa é comum misturarem vários tipos de bebidas, e esse consumo exagerado acaba funcionando para se liberarem de constrangimentos e entrar num clima mais ébrio e eufórico.

Não obstante, o consumo de certas bebidas acaba se convertendo num bem simbólico de dissimilação. O interessante neste caso é que são bens que fazem parte do consumo conspícuo de classes sociais mais afluentes. Um exemplo disso são jovens que cotizam em grupo para comprar, consumir e ostentar bebidas de grife na festa, como os uísques da marca Johnnie Walker. Por isso, na linguagem comum que utilizam, ser patrão é ostentar um bem escasso na periferia e reconhecido como símbolo de prestígio.

São distinções que não alteram a condição de classe, mas alteram as visibilidades sociais e espaciais em seu meio; é o poder que têm para mostrar que não são zé ninguéns ou seja, alguém sem visibilidade e posses. Para fugir desse rótulo a ostentação e consumo de bens simbólicos prestigiados os possibilita guindar para uma maior visibilidade social.

Contudo, é preciso salientar que não são todos os jovens da periferia ou mesmo da festa do fluxo que buscam esse tipo de visibilidade; outros são mais reservados e buscam a diversão como uma finalidade em si mesma. A festa também é, no todo, uma forma de dissidência estética, pois são corpos que, nas danças, nos tipos de músicas e nas roupas, não encontram aceitação fora da periferia. É no fluxo que podem externar suas corporeidades, gostos e preferências.

\section{CONSIDERAÇÕES FINAIS}

O que é o fluxo? É uma prática espacial? Os resultados a que se chega confirmam que não somente é uma prática espacial festiva, aglomerativa e rizomática, mas que é produzida por agentes sociais em situação periférica, não apenas espacial como socialmente. É uma festa que estabelece um campo de diversão, dissimilação e divergências.

E um dos sentidos êmicos do fluxo enquanto prática para os jovens é o de não estar parado, estar no movimento e na ação de acompanhar a diversão onde ela estiver acontecendo. Mostram a capacidade de se articular em tempo real e de criar estratégias para burlar as instâncias normativas e da ordem, como do aparelhamento policial, que muitas vezes os reprime. 
É uma festa que demonstra as estratégias criativas, inovadoras e, de certa forma, subversivas e anárquicas desses jovens periféricos, jovens que se movem, saltam as escalas na cidade e constroem, ainda que de forma espontânea e transitória, uma territorialidade no espaço urbano. É um lugar onde podem negociar entre eles seus códigos e produções simbólicas.

São jovens que, no âmbito do consumo, reconhecem a seu modo um espaço social dividido e a divisão e classificação social como princípio da distribuição de bens e valores da sociedade em que estão perifericamente inscritos. Por isso, também incorporam valores de outras classes sociais, como forma de buscarem alguma visibilidade social.

Por fim, as redes e microculturas juvenis nas suas microterritorialidades rizomáticas constituem uma força territorial e gregária na cidade e expressam uma vontade coletiva dos jovens de viver seus gostos e buscar seus interesses. E suas práticas espaciais demonstram uma periferia urbana não isolada em fragmentos, mas articulada pela força dos vários tipos de agenciamentos, entre os quais aqueles praticados pelos jovens e suas festas na periferia.

\section{AGRADECIMENTOS}

À FAPESP - Fundação de Amparo à Pesquisa do Estado de São Paulo pelo apoio financeiro essencial para realização dessa pesquisa.

À UFMS - Fundação Universidade Federal do Mato Grosso do Sul pelo apoio a pesquisa.

\section{REFERÊNCIAS}

BOURDIEU, P. A distinção: crítica social do julgamento. São Paulo: Edusp; Porto Alegre, RS: Zouk, 2007.

BOURDIEU, P. Capital simbólico e classes sociais. Novos Estudos - CEBRAP, n. 96, p. 105-115, jul. 2013. https://doi.org/10.1590/S0101-33002013000200008

CASTRO, I. E. O Problema da Escala. In: CASTRO, I. E.; GOMES, P. C; CORRÊA, R.L. Geografia: conceitos e temas. Rio de Janeiro: Bertrand Brasil, 2009. p. 117-141.

CERTEAU, Michel de. A invenção do cotidiano: artes de fazer. Petrópolis: Vozes, 1994.

CLIFFORD, J. Culturas Viajantes. In: ARANTES, Antônio A. O Espaço da Diferença. São Paulo: Papirus, 2000. p. 51-79.

DIÓGENES, G. Cartografias da cultura e da violência: gangues e o movimento hip hop. São Paulo: Annablume, 1998.

FERREIRA, V. S. Ondas, cenas e microculturas juvenis. Plural, Rev. Programa de Pós-Graduação em Sociologia da Universidade de São Paulo, v. 15, p. 99-128, 2008. https://doi.org/10.11606/issn.2176-8099.pcso.2008.75231

GUIMARÃES, Eloisa. Juventude(s) e periferia(s) urbanas. Revista Brasileira de Educação, n.5, p. 199-208, 1997.

GOFFMAN, E. Comportamentos em lugares públicos. Editora Vozes: Petrópolis, 2010.

HAESBAERT. R. O mito da desterritorialização: do "fim dos territórios" à multiterritorialidade. Rio de Janeiro: Bertrand Brasil, 7 ed, 2012.

HIERNAUX, D. Repensar la ciudad: La dimensión ontológica de lo urbano. Revista LiminaR. Estudios Sociales y humanísticos, v. 4, p. 7-17, 2006. https://doi.org/10.29043/liminar.v4i2.207

JEOLÁS, L. S. O canto dos motores: expressão e produção de sentidos entre rachadores de carros e motos. In.: II Encontro Internacional sobre Imaginários Sonoros, 2013 Curitiba. Disponível em: http://www.humanas.ufpr.br/portal/imaginariossonoros/files/2014/02/Leila-Jeolas-Imaginários2013.pdf. Acesso em 12/11/2015.

KOZINETS, R. V. Netnografia: realizando pesquisa etnográfica online. Porto Alegre: Penso Editora, 2014. 
MAFFESOLI, M. O tempo das tribos: o declínio do individualismo nas sociedades de massa. Rio de Janeiro: Forense Universitária, 1998.

MAGNANI, J. G. C. De perto e de dentro: notas para uma etnografia urbana. Revista Brasileira de Ciências Sociais, v. 17, n. 49, p. 11-29, 2002. https://doi.org/10.1590/S0102-69092002000200002

MAGNANI, J. G. C. Os circuitos dos jovens urbanos. Tempo Social, v. 17, n. 2. p. $173-205,2005$. https://doi.org/10.1590/S0103-20702005000200008

MARSTON, S. A. The social construction of scale. Progress in Human Geography, v. 24, n. 2, p. 219-242, 2000. https://doi.org/10.1191/030913200674086272

MASSEY. D. Filosofia e política da espacialidade: algumas considerações. Rev. Geographia, Niteroi, ano VI, n. 2, p. 7-23, 2004.

MASSEY, D. Pelo espaço: uma nova política da espacialidade. Rio de Janeiro: Bertrand Brasil, 2008. p. 312.

MASSEY, D. A mente geográfica. Geographia, v. 19, n. 2006, p. 36-40, 2017. https://doi.org/10.22409/GEOgraphia2017.1940.a13798

NASCIMENTO, E. P. A periferia de São Paulo: revendo discursos, atualizando o debate, Revista Rua, v. 2, n. 16, p. 111-128, 2010. https://doi.org/10.20396/rua.v16i2.8638822

OLIVE, J. L. Reflecting on the tensions between emic and etic perspectives in life history research: Lessons learned. Forum Qualitative Sozialforschung, v. 15, n. 2, 2014.

PAIS, J. M. Culturas juvenis, 2 ed. Lisboa: Imprensa Nacional. Casa da moeda, 2003.

PALLARÉS J. G.; FEIXA, C. Espacios e itinerarios para el ocio juvenil nocturno. Rev. Estudios de Juventud, n. 50, p. 23-41, 2000.

RAFFESTIN, C. Por uma Geografia do Poder. Editora Ática, São Paulo, 1993 [1980].

RAMOS, E.C.M. As culturas juvenis a partir da perspectiva socioespacial e o caso dos "rolezinhos" nos shopping centers em duas cidades médias. Ciência Geográfica, n. 1, Jan/Dez, 2015. https://doi.org/10.22409/GEOgraphia2018.v1i44.a14392

RAMOS, E.C.M. Tudo junto e misturado, rolês e fluxos dos jovens da periferia: capital espacial construído por redes juvenis no campo da diversão e geometrias de poder na cidade. 2017, 477 p. Tese (doutorado) - Universidade Estadual Paulista (UNESP). Faculdade de Ciência e Tecnologia. Departamento de Pós-Graduação em Geografia. Presidente Prudente.

RAMOS, E.C.M. A Construção do capital espacial e da visibilidade social pela Microcultura juvenil do Low na Cidade de Marília/SP. Geographia (UFF), v. 20, p.107 - 120, 2018a.

SMITH, N. Contornos de uma política espacializada: veículos dos sem teto e produção de escala geográfica. In: ARANTES, A. A. (org.). O espaço da diferença. São Paulo: Papirus, 2000. p. 132175.

TURRA NETO, N. Múltiplas trajetórias juvenis: territórios e rede de sociabilidade. Jundiaí: Paco Editorial, 2012.

TURRA NETO, N. Metodologias de pesquisa qualitativa para o estudo geográfico da sociabilidade juvenil. Revista RA'EGA, n.23, Curitiba, UFPR, 2011, p. 340-375. https://doi.org/10.5380/raega.v23i0.24843

Recebido em: 28/11/2019

Aceito para publicação em: 06/08/2020 